\section{The influence of process conditions on ground coal slag and blast furnace slag based geopolymer properties}

Rudarsko-geološko-naftni zbornik

(The Mining-Geology-Petroleum Engineering Bulletin) UDC: 620

DOI: $10.17794 / \mathrm{rgn} .2020 .4 .2$

Preliminary communication

\author{
Quyen V. Trinh ${ }^{1,2}$; Gábor Mucsi3; Thai V. Dang ${ }^{1,2}$; Ly. LePhuong4; Van H. Bui5; Sándor Nagy3 \\ ${ }^{1}$ Institute of Theoretical and Applied Research, Duy Tan University, Hanoi, 100000, Vietnam \\ ${ }^{2}$ Faculty of Environmental and Chemical Engineering, Duy Tan University, Da Nang, 550000, Vietnam \\ ${ }^{3}$ Institute of Raw Material Preparation and Environmental Processing, University of Miskolc, H-3515 Miskolc Egyetemváros, Miskolc, Hungary \\ ${ }^{4}$ Institute of Concrete Technology, Nghia Tan, Cau Giay, Hanoi, 100000, Vietnam \\ ${ }^{5}$ Faculty of Physics, VNU Hanoi University of Science, 334 Nguyen Trai, Hanoi, 100000, Vietnam
}

\begin{abstract}
In this study, the material characterization of Vietnamese ground coal slag and ground granulated blast furnace slag (GGBFS), such as particle size distribution, chemical composition, bulk density and particle density are shown. The geopolymer specimens were prepared by mixing an $80 \mathrm{~m} / \mathrm{m} \%$ mass of solid materials (ground coal slag and GGBFS in a different ratio) with $20 \mathrm{~m} / \mathrm{m} \%$ of a $10 \mathrm{M} \mathrm{NaOH}$ alkaline activator. A systematic experimental series was carried out in order to optimize the preparation process. In that series, the heat curing temperature was $60^{\circ} \mathrm{C}$ for 6 hours, and then selected specimens were heat treated at a high temperature $\left(1000^{\circ} \mathrm{C}\right)$ for 1 hour. After 7 days of ageing, the physical properties of the geopolymer (compressive strength, specimen density) were measured. Also, after 180 days of ageing, the $\mathrm{pH}$ values of water in the geopolymer leaching preparation were determined. The results show that the geopolymer can be used for refractory applications due to its good heat resistance properties. However, geopolymers that were heated at $1000^{\circ} \mathrm{C}$ had lower compressive strength, specimen density and $\mathrm{pH}$ values of water containing the geopolymer than those that were cured at $60^{\circ} \mathrm{C}$.
\end{abstract}

Keywords:

Coal slag, blast furnace slag, compressive strength, geopolymer.

\section{Introduction}

Davidovits $(1988,1994)$ proposed that certain alkaline liquids could be used to react with the silicon $(\mathrm{Si})$ and aluminum $(\mathrm{Al})$ bearing phases of various raw materials of geological origin or with by-product materials to produce binders. Since the chemical reaction that takes place in this case is a polymerization process, he coined the term 'geopolymer' to represent these binders.

The fire-resistant character of geopolymers has led them to be suggested for use in applications where fire damage can be critical for the structure or its occupants. Special geopolymer formulations are suitable for refractory applications. Low water content and highly pure geopolymers suit industrial refractory applications where the material may be subjected to temperatures in excess of $1200^{\circ} \mathrm{C}$ (Riessen et al., 2009).

Blast furnace slag (abbreviated GGBFS, for 'ground granulated blast furnace slag') is broadly described as a mixture of poorly crystalline phases with compositions resembling gehlenite $\left(2 \mathrm{CaO} \cdot \mathrm{Al}_{2} \mathrm{O}_{3} \cdot \mathrm{SiO}_{2}\right)$ and akerman-

Corresponding author: Quyen V. Trinh

trinhvanquyen@duytan.edu.vn ite $\left(2 \mathrm{CaO} \cdot \mathrm{MgO} \cdot 2 \mathrm{SiO}_{2}\right)$, as well as depolymerized calcium silicate glasses (Tsuyuki and Koizumi, 1999). The degree of depolymerization largely controls reactivity. As slag is generated at a high temperature as a liquid in the blast furnace during iron production and subsequently quenched, its composition is essentially that of an overcharge-balanced calcium aluminosilicate framework - i.e., there is more than sufficient calcium available to charge-balance aluminum, with the remainder contributing to depolymerizing the glass network (Duxson, 2009).

Villarreal et al. (2011) studied that the existence of an optimum curing temperature, $60^{\circ} \mathrm{C}$ to obtain the best geopolymerization process for their circumstances. According to our previous research Trinh et al. (2019) in the case of ground coal slag (maximum particle size 262 $\mu \mathrm{m}$ ) based geopolymer, the optimal conditions were as follows: $80 \mathrm{~m} / \mathrm{m} \%$ ground coal slag and $20 \mathrm{~m} / \mathrm{m} \%$ of $10 \mathrm{M} \mathrm{NaOH}$, which resulted in the highest compressive strength $\left(7.45 \mathrm{~N} / \mathrm{mm}^{2}\right)$.

Do et al. (2019) studied fly ash-based geopolymer concrete using a sodium silicate solution and seawater. They had very good performance with a value of 180 day-compressive strength of $58 \mathrm{MPa}$, water absorption 

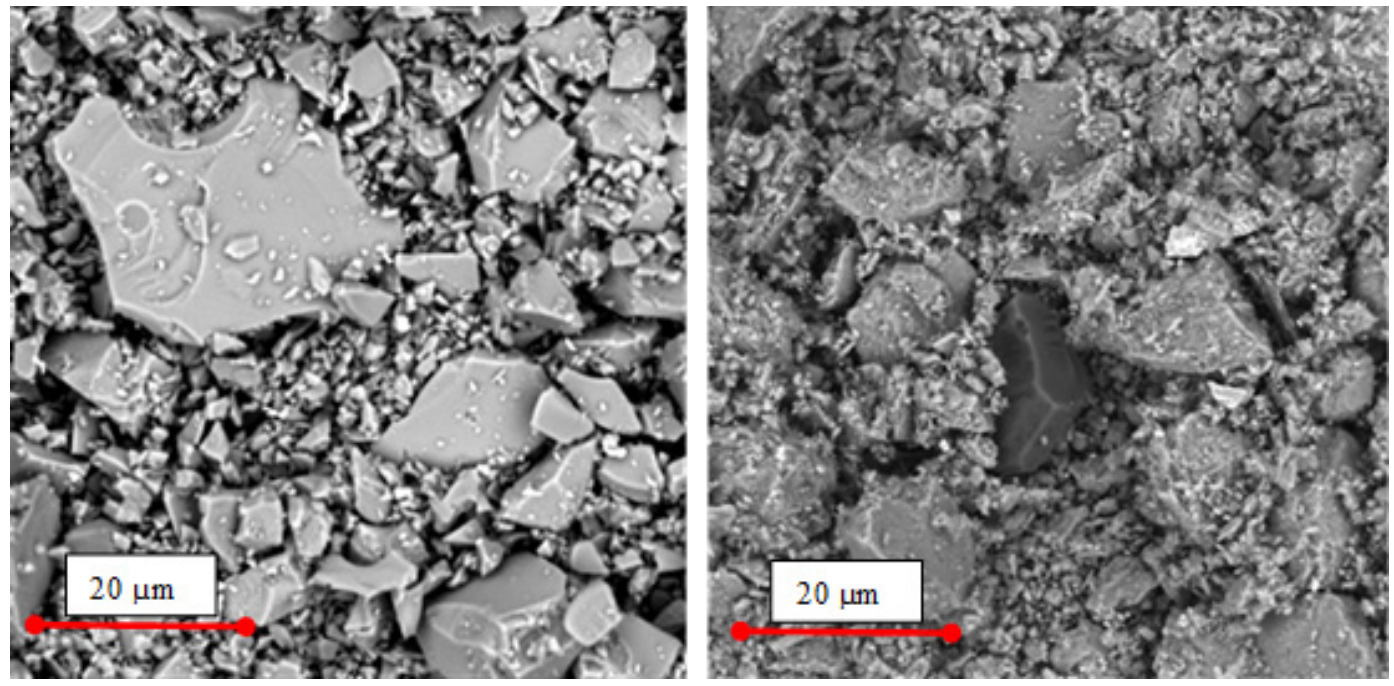

Figure 1: Scanning electron micrographs of GGBFS (left) and ground coal slag (right)

and volumetric weight were $180 \mathrm{~kg} / \mathrm{m}^{3}$ and $2200 \mathrm{~kg} / \mathrm{m}^{3}$, respectively. The effect of steel slag substitution as a coarse aggregate on compressive strength in fly ash based-geopolymer concrete was studied by Ashadi et al. (2015). The corrosion rate of geopolymer concrete with a steel slag substitution was found to be lower compared to normal geopolymer concrete. The corrosion rate was found to be very high at an early stage and decreased with time.

Based on the Decision No 428/QD-TTg, the Prime Minister of Vietnam approved the adjustment of the National Power Development Plan VII, on March $18^{\text {th }}$, 2016 , total fly ash, coal slag generated from thermal power plants by 2020 is estimated at 22.6 million tons per year. In Vietnam, the iron and steel industry has developed rapidly and therefore the generation of blast furnace slag increases considerably. The annual production is predicted to exceed 7 million tons in 2020 (Le, 2016). According to Kumar et al. (2015), the different size fractions of fly ash collected from different hoppers have significant variations in chemistry, mineralogy, particle size distribution and glass content. Bedeković et al. (2019) reported that a non-structural polystyrene concrete can be produced by using waste granulated expanded polystyrene. The strength and bulk density of polystyrene concrete increases with an increase in the proportion of sand and cement.

Petlovanyi et al. (2019) investigated the use of manmade formations and the recycling of the valuable extracted components (including microspheres), such as an active mineral admixture and small aggregate in light, heavy concrete and artificial cement, an analog for clay parts in the production of a cement clinker, and the production of ceramic bricks, a component for the preparation of hardening backfill. Krupnik et al. (2020) studied whether or not polymer concrete is able to replace metal as the transfer case component in production. Actually, it has a number of advantages: less product weight, high strength, and resistance to corrosion. Kumar et al. (2005) proved that the addition of mechanically activated slag to a clinker and replacing the clinker with ground slag can produce better compressive strength and a better hydration reaction.

Mucsi et al. (2014, 2015, 2019) reported that the optimum $\mathrm{NaOH}$ concentration of the alkaline activator was $8 \mathrm{M}$ for $60{ }^{\circ} \mathrm{C}$ heat treatment (the maximum compressive strength was $14.3 \mathrm{MPa}$ ) and $10 \mathrm{M}$ for $90^{\circ} \mathrm{C}$ in cases of ground fly ash base geopolymers. Geopolymerization of mechanically activated fly ash has been carried out with various proportions of red mud ranging between 0 - $30 \%$ by weight, and the compressive strength of fly ash based geopolymers increased with the addition of up to $15 \%$ of red mud. A strong relationship was shown between the geopolymer physical property (compressive strength) and fly ash fineness (median particle size, specific surface area) and relative span. Nguyen and Chu,

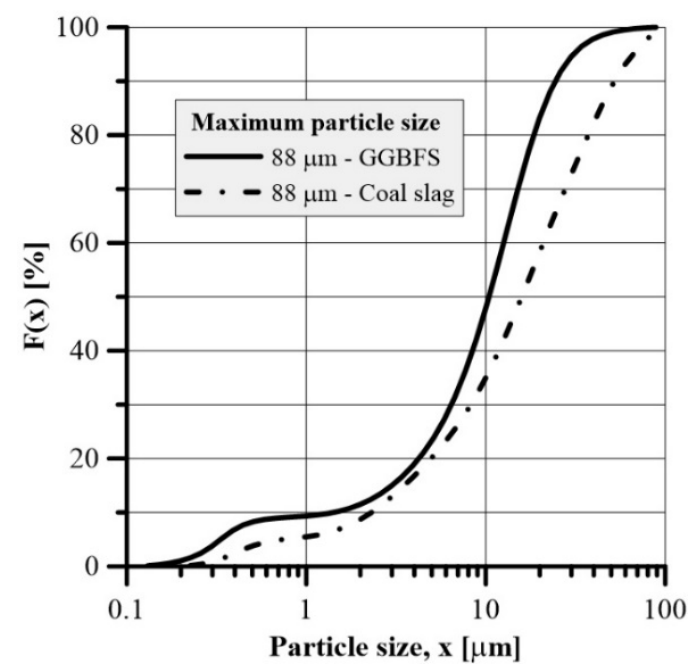

Figure 2: Particle size distribution of ground coal slag and GGBFS samples 
(2020) revealed that $30 \%$ GBFS in the replacement of cement is suitable content in this sand concrete.

Therefore, in order to ensure the stable operation of coal-fired power plants and different steel plants, it is necessary to urgently seek solutions to consume coal slag, fly ash and blast furnace slag which continue to arise and exist in the storage areas. Based on the above problems, the goal of our research was to optimize the production process of coal- and metallurgical slag based geopolymers.

\section{Materials and methods}

\subsection{Materials}

Ground coal slag and ground granulated blast furnace slag (GGBFS) were selected for the production of building materials and reducing environmental pollution. Coal slag which originated from the Quang Ninh province and Vietnam (Mao Khe Thermal Power Plant), and GGBFS which originated from the Hai Dương province and Vietnam (Hoa Phat Hai Duong steel joint stock company) were used for our experiments.

Each type of raw material was analyzed through scanning with an electron microscope (see Figure 1). It can be observed that the ground coal slag and GGBFS are regularly shaped with a spherical form and compact structure.

The particle size distribution of ground coal slag and GGBFS samples were determined using a Horiba LA950 V2 type laser particle size analyzer, as shown in Figure 2. Specific surface areas were calculated by laser sizer software. In the case of ground coal slag, the characteristic particle size values were as follows: $x_{10}=2.3 \mathrm{~mm}$, $\mathrm{x}_{50}=15.8 \mathrm{~mm}, \mathrm{x}_{90}=52 \mathrm{~mm}$, and the specific area was $14533 \mathrm{~cm}^{2} / \mathrm{g}$. In the case of GGBFS, these values were $\mathrm{x}_{10}=1.4 \mathrm{~mm}, \mathrm{x}_{50}=10.4 \mathrm{~mm}, \mathrm{x}_{90}=24 \mathrm{~mm}$, and the specific area was $25655 \mathrm{~cm}^{2} / \mathrm{g}$.

Based on XRF (type: Supermini200) analysis, the measured chemical composition of GGBFS and ground coal slag are given in Table 1. Analysis of the $\mathrm{SiO}_{2} / \mathrm{AlO}_{3}$ ratio determined it was 2.2 and the sum of the $\mathrm{SiO}_{2}$, $\mathrm{Al}_{2} \mathrm{O}_{3}$ and $\mathrm{Fe}_{2} \mathrm{O}_{3}$ content of the ground coal slag was $82.51 \mathrm{~m} / \mathrm{m} \%$. In the case of GGBFS, the $\mathrm{SiO}_{2} / \mathrm{AlO}_{3}$ ratio was 3.8 and the sum of the $\mathrm{SiO}_{2}, \mathrm{Al}_{2} \mathrm{O}_{3}$ and $\mathrm{Fe}_{2} \mathrm{O}_{3}$ content of the ground coal slag was $49 \mathrm{~m} / \mathrm{m} \%$. The GGBFS is a nonmetallic product, consisting essentially of silicates and aluminosilicates of calcium and other bases. The major oxide phases consist of $\mathrm{SiO}_{2}, \mathrm{CaO}, \mathrm{Al}_{2} \mathrm{O}_{3}$, and $\mathrm{MgO}$. Others minor oxides are: $\mathrm{Fe}_{2} \mathrm{O}_{3}, \mathrm{Na}_{2} \mathrm{O}, \mathrm{TiO}_{2}$, and $\mathrm{P}_{2} \mathrm{O}_{5}$.

In the determination of the loss on ignition (L.O.I.), $1.0 \mathrm{~g}$ of a burned powder sample was used, every sample was analyzed 3 times, and these values were averaged. The values were $2.5 \mathrm{~m} / \mathrm{m} \%$ in the case of GGBFS and $3.52 \mathrm{~m} / \mathrm{m} \%$ in the case of ground coal slag.
Table 1: Chemical composition, moisture content and density of the GGBFS and coal slag

\begin{tabular}{|l|c|c|}
\hline \multirow{2}{*}{ Components } & \multicolumn{2}{|c|}{ Mass concentration [m/m\%] } \\
\cline { 2 - 3 } & GGBFS & Coal slag \\
\hline $\mathrm{SiO}_{2}$ & 38.7 & 54.4 \\
\hline $\mathrm{Al}_{2} \mathrm{O}_{3}$ & 10.2 & 24.2 \\
\hline $\mathrm{MgO}$ & 7.35 & 1.40 \\
\hline $\mathrm{CaO}$ & 28.7 & 1.30 \\
\hline $\mathrm{Na}_{2} \mathrm{O}$ & 0.36 & 0.43 \\
\hline $\mathrm{K}_{2} \mathrm{O}$ & 1.08 & 3.59 \\
\hline $\mathrm{Fe}_{2} \mathrm{O}_{3}$ & 0.15 & 3.91 \\
\hline $\mathrm{MnO}_{2}$ & 1.31 & 0.029 \\
\hline $\mathrm{TiO}_{2}$ & 0.36 & 0.781 \\
\hline $\mathrm{P}_{2} \mathrm{O}_{5}$ & 0.029 & 0.077 \\
\hline $\mathrm{S}$ & 1.49 & 1.17 \\
\hline $\mathrm{F}$ & $<0.3$ & $<0.3$ \\
\hline Moisture content & $4 \mathrm{~m} / \mathrm{m} \%$ & $3.3 \mathrm{~m} / \mathrm{m}^{\circ} \%$ \\
\hline Bulk density & 1068 & $1537 \mathrm{~kg} / \mathrm{m}^{3}$ \\
\hline
\end{tabular}

\subsection{Experimental procedure}

\subsubsection{Geopolymer production}

The geopolymer samples were produced by mixing an $80 \mathrm{~m} / \mathrm{m} \%$ mass of materials (including ground coal slag and GGBFS in different ratios) with $20 \mathrm{~m} / \mathrm{m} \%$ of $10 \mathrm{M} \mathrm{NaOH}$. The compacted mixture was kept in molds for 24 hours insulated at ambient temperature. One part of the geopolymer was heat cured at $60^{\circ} \mathrm{C}$ for 6 hours by oven and the other part of the geopolymer was heat treated at a high temperature $\left(1000^{\circ} \mathrm{C}\right)$ for 1 hour in a furnace. After that, the specimens were cooled down to ambient temperature. The compressive strength tests were carried out using a Compression Testing Machine after a period of 7 days. The $\mathrm{pH}$ values of geopolymer leaching were measured in the case of heat treated at $60{ }^{\circ} \mathrm{C}$, $1000^{\circ} \mathrm{C}$ and 180 days old.

\subsubsection{Measurement of density and compressive strength}

The geometric parameters of the cubic samples were measured by a Vernier caliper, mass was measured, and density was calculated. For compressive strength, $20 \mathrm{x}$ $20 \times 20 \mathrm{~mm}$ cubic samples were prepared by vibro-casting of geopolymer paste. Compressive strength was tested on an Automatic Compression Testing Machine SZF-1 type hydraulic 7 days after casting the samples at $27^{\circ} \mathrm{C}$ followed by curing at $60^{\circ} \mathrm{C}$ for 6 hours and heating at a high temperature $\left(1000{ }^{\circ} \mathrm{C}\right)$. The average from three samples was determined for each result.

\subsubsection{The $\mathrm{pH}$ measurement}

For the ground coal slag and GGBFS, each geopolymer sample at $60{ }^{\circ} \mathrm{C}, 1000{ }^{\circ} \mathrm{C}$ and 180 days old was soaked with $50 \mathrm{ml}$ of distilled water for 10 days. Then the 
$\mathrm{pH}$ values of water in the geopolymer leaching preparation were measured by a $\mathrm{pH}$ meter (type HI 3220).

\section{Results and discussion}

\subsection{Ground coal slag and GGBFS based geopolymer}

In this part, the geopolymer samples are shown in Figure 3. The research results are presented focusing on the relationship between geopolymer heating at a high temperature with those mechanical properties. In the case of geopolymer cubic specimens which were cured at room temperature for 7 days, the geopolymer made at $60{ }^{\circ} \mathrm{C}$ had a better interface than those made at $1000^{\circ} \mathrm{C}$. However, it was observed that a white powder (efflorescence) appeared on the geopolymer surface, when the geopolymer made of $100 \%$ GGBFS was heat treated at $60{ }^{\circ} \mathrm{C}$ and after 180 days of ageing, while efflorescence has not appeared on the geopolymer surface when the geopolymer made of $100 \%$ GGBFS was heat treated at $1000{ }^{\circ} \mathrm{C}$ and after 180 days of ageing.

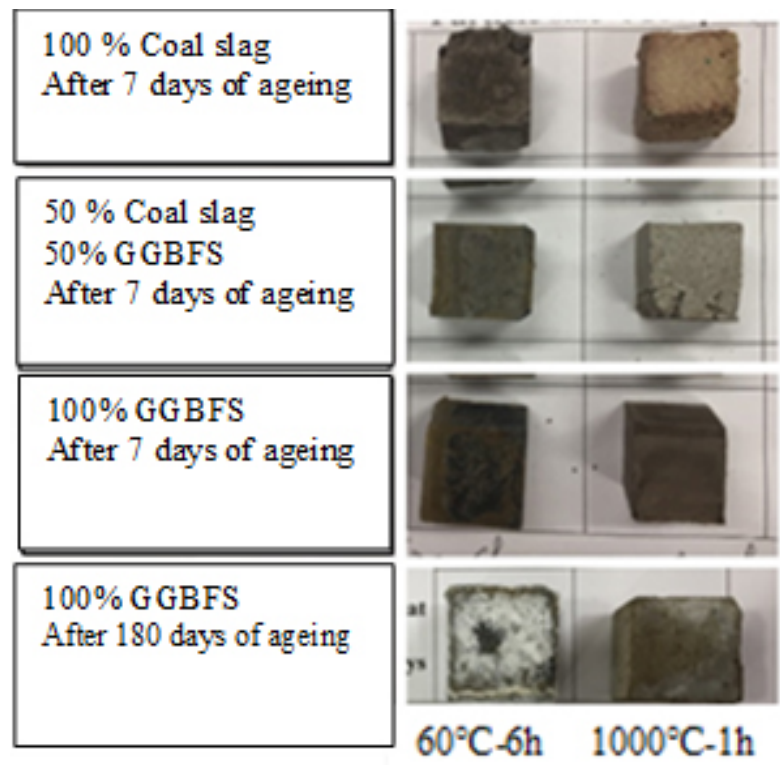

Figure 3: Geopolymer cubic specimens produced from ground coal slag and GGBFS

The reason for this may be the high amount of $\mathrm{Na}$ in the geopolymer, which has been released from the geopolymer sample in the case of $60{ }^{\circ} \mathrm{C}$ heat treated after 180 days of ageing. Otherwise, the excess $\mathrm{Na}$ exists in the geopolymer and is built into the structure due to the high temperature treatment $\left(1000^{\circ} \mathrm{C}\right)$.

It was observed that an increase in the GGBFS mass ratio resulted in higher compressive strength and density of geopolymer cubic specimens. In the case of specimens heat cured at $60{ }^{\circ} \mathrm{C}$, the highest compressive strength (CS) was $49 \mathrm{~N} / \mathrm{mm}^{2}$, and the highest specimen density (SD) was found to be $2.15 \mathrm{~g} / \mathrm{cm}^{3}$, which was for a $100 \%$ GGBFS mass ratio. The lowest compressive strength $\left(30 \mathrm{~N} / \mathrm{mm}^{2}\right)$ and the lowest specimen density $\left(1.69 \mathrm{~g} / \mathrm{cm}^{3}\right)$ was for a $100 \%$ ground coal slag. In the case of specimens heat-treated at $1000{ }^{\circ} \mathrm{C}$, the highest compressive strength was $45 \mathrm{~N} / \mathrm{mm}^{2}$, and the highest specimen density was $2.14 \mathrm{~g} / \mathrm{cm}^{3}$, which was for a $100 \%$ GGBFS mass ratio. The lowest compressive strength was $25 \mathrm{~N} / \mathrm{mm}^{2}$ and the lowest specimen density was $1.64 \mathrm{~g} / \mathrm{cm}^{3}$, which was for a $100 \%$ ground coal slag (see Figure 4).

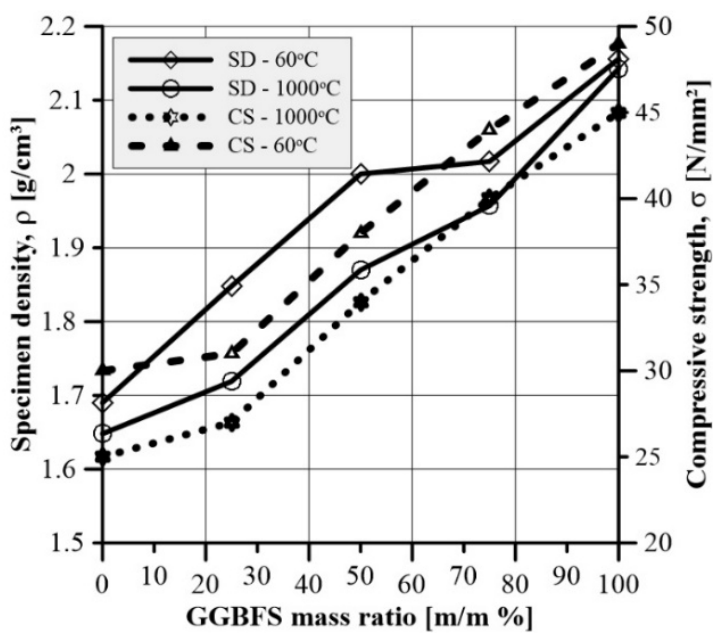

Figure 4: Effect of GGBFS mass ratio on the geopolymer mechanical properties

The reason for that is that generally, GGBFS was effectively used as a mineral admixture in modifying the microstructure of geopolymers and also in the polymerization process. It also developed very good binding properties with alkaline liquids to yield a better strength and alkali activation process (Rajarajeswari and Dhinakaran, 2016).

\subsection{The influence of $\mathrm{pH}$ on the leaching behavior of geopolymers}

In the case of the geopolymer cubic samples kept at $1000{ }^{\circ} \mathrm{C}$ for 1 hour, geopolymers made from a higher GGBFS mass ratio had higher $\mathrm{pH}$ values of water in the geopolymer preparation. In the case of the difference in heating temperatures, geopolymers which were heated

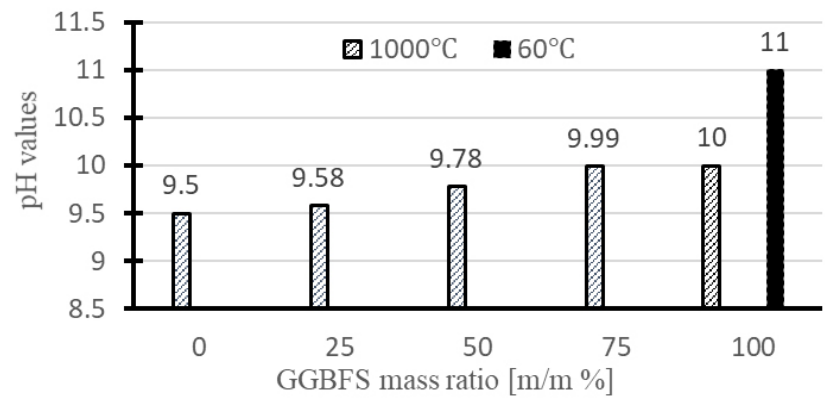

Figure 5: The $\mathrm{pH}$ values of water in the geopolymer leaching 
at $1000{ }^{\circ} \mathrm{C}$ had lower $\mathrm{pH}$ values than those that were cured at $60{ }^{\circ} \mathrm{C}$ (see Figure 5).

The reason for that is the fact that the thermal treatment temperature influences the $\mathrm{pH}$ values of the aluminosilicates. The higher the temperature, the lower the $\mathrm{pH}$ values of the geopolymer (Davidovits, 2008).

\section{Conclusions}

The present study investigated the compressive strength of ground coal slag and GGBFS based geopolymer (mixing $80 \mathrm{~m} / \mathrm{m} \%$ mass of solid materials with 20 $\mathrm{m} / \mathrm{m} \%$ of $10 \mathrm{M} \mathrm{NaOH}$ alkaline activator) cured at $60^{\circ} \mathrm{C}$ and heat treated at $1000{ }^{\circ} \mathrm{C}$, after 7 days of ageing. Additionally, the $\mathrm{pH}$ values of water in geopolymer leaching were determined after 180 days of ageing.

If the same production condition (after 7 days of ageing, $20 \% \mathrm{~m} / \mathrm{m}$ of $10 \mathrm{M} \mathrm{NaOH}$ ), the increase in the GGBFS mass ratio resulted in a higher compressive strength (25 - $45 \mathrm{MPa}$ range at $1000{ }^{\circ} \mathrm{C} ; 30$ - $49 \mathrm{MPa}$ range at $\left.60{ }^{\circ} \mathrm{C}\right), \mathrm{pH}$ values of water in the geopolymer leaching $\left(9.5\right.$ - 10 range at $\left.1000^{\circ} \mathrm{C}\right)$ and specimen density of geopolymer cubic specimens $\left(1.64-2.14 \mathrm{~kg} / \mathrm{m}^{3}\right.$ range at $1000{ }^{\circ} \mathrm{C} ; 1.69-2.15 \mathrm{~kg} / \mathrm{m}^{3}$ range at $60{ }^{\circ} \mathrm{C}$ ). The geopolymer cubic specimens kept at $1000^{\circ} \mathrm{C}$ had lower values of water $\mathrm{pH}$ in geopolymer leaching, compressive strength, and specimen density than those kept at $60^{\circ} \mathrm{C}$.

In the case of geopolymer cubic specimens, which were cured at room temperature for 180 days, the relationship between the geopolymer interface and the heating temperature were determined. Geopolymer quality can be improved by thermal treatment at $1000{ }^{\circ} \mathrm{C}$ (the efflorescence did not appear on the geopolymer surface). Therefore, the optimal production process was $100 \%$ GGBFS content geopolymer consisting of $80 \mathrm{~m} / \mathrm{m} \%$ of GGBFS with $20 \mathrm{~m} / \mathrm{m} \%$ of $10 \mathrm{M} \mathrm{NaOH}$ and heat treated at $1000{ }^{\circ} \mathrm{C}$.

The addition of sea-water and water-glass to the activator solution in the case of a GGBFS and a ground coal slag based geopolymer should be studied in future work.

\section{Acknowledgements}

The described work was carried out as part of the Innovative fine grinding - particle design technologies laboratory development at the University of Miskolc in the Centre of Excellence on Sustainable Natural Resources Management, GINOP-2.3.3-15-2016-00019 project in the framework of the Széchenyi 2020 Program. The realization of this project is supported by the European Union, co-financed by the European Social Fund.

The research work was performed in the Centre of Excellence in Sustainable Natural Resource Management at the Faculty of Earth Science and Engineering, University of Miskolc and Laboratory of Applied Nanotechnology, Duy Tan University. The described article was carried out as part of the "Sustainable Raw Material Management Thematic Network - RING 2017', EFOP3.6.2-16-2017-00010 project in the framework of the Széchenyi2020 Program. The realization of this project is supported by the European Union, co-financed by the European Social Fund. Furthermore, the authors greatly appreciate the help of Ákos Debreczeni and Nóra Halyag for providing the results of the strength and SEM tests they carried out.

\section{References}

Ashadi, W.H., Aprilando, A.B., Astutiningsih, S. (2015): Effects of steel slag substitution in geopolymer concrete on compressive strength and corrosion rate of steel reinforcement in seawater and an acid rain environment. International Journal of Technology, 2, 227-235.

Bedeković, G., Grčić, I., Anić Vučinić, A., Premur, V. (2019): Recovery of waste expanded polystyrene in lightweight concrete production. Rudarsko geološko naftni zbornik (The Mining-Geology-Petroleum Engineering Bulletin), Vol 34, N. . 3, 73-80, DOI: 10.17794/rgn.2019.3.8

Davidovits, J. (1988): Geopolymer chemistry and properties. Proceedings of the 1st International Conference on Geopolymer 88. In: Joseph Davidovits and Joseph Orlinski (eds), Compiegne, France, 1-3 June, Vol. 1, 25-48.

Davidovits, J. (1994): Properties of geopolymer cements. Proceeding of the first International Conference on Alkaline Cement and Concretes. Kiev State Technical University, Ukraina, 131-149.

Davidovits, J. (2008): Geopolymer chemistry and application, $2^{\text {nd }}$ edition June 2008. Institute of Geopolymer, 414p, ISBN 13: 9782951482012.

Decision No 428/QD-TTg (March 2016): Decision on the approval of the revised national power development master plan for the 2011-2020, period with the vision to 2030 . http://gizenergy.org.vn/media/app/media/PDF-Docs (accessed $1^{\text {st }}$ June 2020).

Do Q. M., Bui T. H., Nguyen H. T. (2019): Effects of seawater content in alkaline activators to engineering properties of fly ash-based geopolymer concrete. Solid State Phenomena, Vol. 296, 105-111, ISSN: 1662-9779.

Duxson, P. (2009): Geopolymer precursor design. Woodhead Publishing, University of Melbourne, Australia, 37-49. ISBN 978-1-84569-449-4.

Krupnik, L., Yelemessov, K., Beisenov, B., Baskanbayeva, D. (2020): Substantiation and process design to manufacture polymer-concrete transfer cases for mining machines. Mining of Mineral Deposits. Volume 14 (2020), Issue 2, 103-109.

Kumar, R., Kumar, S., Badjena, S., Mehrotra, S. P. (2005). Hydration of Mechanically Activated Granulated Blast Furnace Slag, Metallurgical and Materials Transactions B, volume 36B, December pp. 873-883.

Kumar, S., Kristály, F., Mucsi, G. (2015): Geopolymerisation behaviour of size fractioned fly ash. Advanced Powder Technology, 26, 24-30.

Le, V.H. (2016): Current situation of the regulations and standards respect to slag application in Vietnam. In: Proceeding 
of Conference on Application of Iron/Steel Slag in Construction Industry for Sustainable Development, Hanoi, 41-52.

Mucsi, G., Kumar, S., Csőke, B., Kumar, R., Molnár, Z., Rácz, Á., Mádai, F., Debreczeni, Á. (2015): Control of Geopolymer Properties by Grinding of Land Filled Fly Ash. International Journal Mineral Processing, 143, 50-58.

Mucsi, G., Lakatos, J., Molnár, Z, Szabó, R. (2014): Development of geopolymer using industrial waste materials. The 9th International Conference "Environmental Engineering", Vilnius, Lithuania. Selected Papers, Article number: Enviro.2014.039. ISSN 2029-7092.

Mucsi, G., Szabó R., Rácz, Á., Kristály, F., Kumar, S. (2019): Combined utilization of red mud and mechanically activated fly ash in geopolymers. Rudarsko geološko naftni zbornik (The Mining-Geology-Petroleum Engineering Bulletin), Vol 34, $\mathrm{N}_{\mathrm{o}}$. 1, 27-36, DOI: 10.17794/rgn.2019.1.3.

Nguyen, T.S., Chu T.H. (2020): Effect of ground blast furnace slag in replacement of cement in ternary binder on performance of sand concrete. Springer Nature Singapore Pte Ltd, 403-408.

Petlovanyi, M., Kuzmenko, O., Lozynskyi1, V., Popovych, V., Sai, K., Saik, P. (2019): Review of Man-Made Mineral
Formations Accumulation and Prospects of Their Developing in Mining Industrial Regions in Ukraine. Mining of Mineral Deposits. Volume 13, Issue 1, 24-38.

Rajarajeswari, A and Dhinakaran, G. (2016): Compressive Strength of Thermal Cured GGBFS Based Geopolymer Concrete. Asian Journal of Civil Engineering (BHRC), Vol. 17, No. 3, 347-355.

Riessen, V.A., Rickard, W., Sanjayan, J. (2009): Thermal properties of geopolymers. In: Provis, J.L and Deventer, J.S.J (eds). Cambridge, UK. -Woodhead Publishing, 315342,338 p.

Trinh, V.Q., Nagy, S., Mucsi, G. (2019): Preliminary geopolymerization experiments of Vietnamese fly ash and slag. MultiScience-XXXIII. microCAD International Multidisciplinary Scientific Conference. University of Miskolc, Hungary, 23-24 May, ISBN 978-963-358-177-3. DOI: 10.26649/musci.2019.009

Tsuyuki, N., and Koizumi, K. (1999): Granularity and surface structure of ground granulated blast-furnace slags. Journal of the American Ceramic Society, 82, 2188-2192.

Villarreal, M.S.M et al. (2011): The effect of temperature on the geopolymerization process of a metakaolin-based geopolymer. Materials Letters, 65, 995-998.

\section{SAŽETAK}

\section{Utjecaj uvjeta postupka dobivanja mljevene troske taljenjem ugljena u visokoj peći uz uporabu geopolimera}

U ovome istraživanju donose se obilježja vijetnamskih granulata ugljene troske i troske željezne rude na osnovi njihove veličine, kemijskoga sastava i gustoće. Uzorci geopolimera pripremljeni su miješanjem $80 \% \mathrm{~m} / \mathrm{m}$ (mase otopljenoga / masa otopine) ugljene i željezne troske (u različitim omjerima) s $20 \% \mathrm{~m} / \mathrm{m}$ 10M NaOH kao alkalnoga aktivatora. Sustavnim serijama eksperimenata optimiziran je postupak pripreme, pri čemu je temperatura iznosila $60^{\circ} \mathrm{C}$ tijekom 6 sati, nakon čega su odabrani uzorci zagrijavani 1 sat na $100{ }^{\circ} \mathrm{C}$. Nakon sljedećih 7 dana izmjerena su fizička svojstva geopolimera (tlačna čvrstoća, gustoća). Zatim je poslije 180 dana određena pH-vrijednost vode korištene u postupku ispiranja geopolimera. Rezultati su pokazali kako geopolimeri mogu biti korišteni za namjene u vatrostalnim uvjetima zahvaljujući toplinskim svojstvima. Također, geopolimeri koji su zagrijavani na $1000{ }^{\circ} \mathrm{C}$ imaju niže vrijednosti tlačne čvrstoće, gustoće i pH-vrijednosti vode u njima od onih koji su grijani na $60^{\circ} \mathrm{C}$.

\section{Ključne riječi:}

ugljena troska, troska visokih peći, tlačna čvrstoća, geopolimer

\section{Author's contribution}

Quyen V. Trinh (Ph.D) initialized the idea, completed literature review and participated in all work stages, such as data analysis and tested its accuracy. Thai V. Dang (Ph.D); Ly P. Le (Ph.D); Van H. Bui (Ph.D) participated in compressive strength and $\mathrm{pH}$ measurement. Gábor Mucsi (Associate Professor) and Sándor Nagy (Associate Professor) managed the whole process and supervised it from the beginning to the end. 